Article

\title{
The Wonder of Humanity in Plato's Dialogues
}

David W. Bollert

\begin{abstract}
SOCRATES: Surely you're following, Theaetetus; it's my impression at any rate that you're not inexperienced in things of this sort.

THEAETETUS: Yes indeed, by the gods, Socrates, I wonder exceedingly as to why (what) in the world these things are, and sometimes in looking at them I truly get dizay.

SOCRATES: The reason is, my dear, that, apparently, Theodorus' guess about your nature is not a bad one, for this experience is very much a philosopher's, that of wondering. For nothing else is the beginning (principle) of philosophy than this, and, seemingly, whoever's genealogy it was, that Iris was the offspring of Thaumas (Wonder), it's not a bad one. - Plato, Theaetetus
\end{abstract}

${ }^{66} \mathrm{~T}$ he safest general characterization of the European philosophical tradition," Alfred North Whitehead once famously remarked, "is that it consists of a series of footnotes to Plato." 1 If there is some truth to Whitehead's remark, if the remark cannot be wholly reduced to or dismissed as mere hyperbole, then one such "series of footnotes" surely stems from Plato's views on wonder. Indeed, the observation that philosophy is grounded in wonder or thaumazein $(\theta \alpha u \mu \alpha \zeta \varepsilon v v)^{2}$ is a part of Plato's philosophical legacy that has been adopted and appropriated by thinkers as

\footnotetext{
1 A. N. Whitehead, Process and Reality: An Essay in Cosmology (New York, NY: Macmillan, 1929), 63.

2 Plato, Theaetetus, 155c-d. Taken from Plato's Theaetetus: Part I of The Being of the Beautiful, trans. by Seth Benardete (Chicago, IL: The University of Chicago Press, 1986). Theaetetus' response to Socrates' suggestion, as rendered by Levett, is also worth noting: "Oh yes, indeed, Socrates, I often wonder like mad what these things can mean; sometimes when I'm looking at them I begin to feel quite giddy." Taken from The Theaetetus of Plato, ed. by Myles Burnyeat, trans. by M.J. Levett (Indianapolis, IN: Hackett Publishing Company, 1990). Levett translates the Greek word buperphuos, which means, amongst other things, "overgrown" or "enormous," as "like mad," thus emphasizing the strange and extraordinary throes in which the philosopher is often trapped. Although wonder gives birth to philosophy, the rational exercise par excellence, the pathos itself borders on madness. On the connection between philosophy, wonder, and madness, see John Sallis, “. . . A Wonder That One Could Never Aspire To Surpass," in The Path of Archaic Thinking, ed. Kenneth Maly (Albany, NY: State University of New York Press, 1995). I am both indebted to and influenced by Sallis' incisive observations in this essay.
} 


\section{BOLLERT 175}

diverse as Aristotle, Hegel, Kierkegaard, Heidegger, and Arendt. ${ }^{3}$ More contemporary thinkers, such as Phillip Fisher, John Llewelyn, R.W. Hepburn, and Mary-Jane Rubenstein, have also sought a deeper understanding of Plato's declaration that the passion or pathos $(\pi \alpha \theta \mathrm{o} \varsigma)$ of wonder constitutes the arche $(\alpha \rho \chi \eta)$, the "beginning" and sustaining "principle," of philosophy. ${ }^{4}$ It is in the Theaetetus, of course, where Socrates tells the dialogue's young namesake that philosophy is born of and nourished by nothing other than thaumazein and, sensibly enough, most scholars and commentators who seek to understand Plato's views on wonder begin with and primarily focus on this dialogue. As rich and revealing as the Theaetetus is on the topic of wonder, other dialogues, e.g., the Phaedrus, Symposium, and Phaedo, also have much to offer in this regard. ${ }^{5}$ One way of coming to terms with Platonic wonder is to examine what types of things in the dialogues elicit the pathos in the first place. My primary goal in this paper is to examine what evokes the wonder of Socrates and his interlocutors in a number of these works, and I will pay particularly close attention to what Plato has to say about the wondrous nature of humanity itself. I will show that Plato depicts Socrates and other characters found in the dialogues, such as the young Theaetetus, as not only wonderers of the first rank, but also true wonders in themselves.

\section{Worth Our Wonder}

SOCRATES: This, too, you'll observe in dogs... and it's a thing in the beast worthy of our wonder. - Plato, Republic

${ }^{3}$ Aristotle, Metaphysics, 982b; G.W.F. Hegel, The Philosophy of History, trans. by J. Sibree (New York, NY: Dover, 1956), 234 [Here Hegel speaks of "Aristotle's dictum that philosophy proceeds from wonder," which, of course, Aristotle inherited from Plato]; Søren Kierkegaard, Stages on Life's Way, ed. and trans. by Howard V. Hong and Edna H. Hong (Princeton, NJ: Princeton University Press, 1988), 347-348; Martin Heidegger, Basic Questions of Philosophy, trans. by Richard Rojcewicz and Andre Schuwer (Bloomington, IN: Indiana University Press, 1994), 135 and passim; Hannah Arendt, "Philosophy and Politics," Social Research, 1 (Spring, 1990), 99 and passim.

4 Phillip Fisher, Wonder, the Rainbow, and the Aesthetics of Rare Experiences (Cambridge, MA: Harvard University Press, 1998); John Llewelyn, "On the saying that philosophy begins in thaumazein," in Post-Structuralist Classics, ed. by Andrew Benjamin (London: Routledge, 1988); R.W. Hepburn, "Wonder," in Wonder and Other Essays (Edinburgh: Edinburgh University Press, 1984); Mary-Jane Rubenstein, Strange Wonder: The Closure of Metaphysics and the Opening of Awe (New York, NY: Columbia University Press, 2009).

5 A word should be said here concerning the chronology of Plato's dialogues. The exact chronology of Plato's dialogues is exceedingly difficult to establish and is the source of considerable disagreement among scholars. For those wishing to explore the matter in great detail, Leonard Brandwood's The Chronology of Plato's Dialogues (Cambridge: Cambridge University Press, 1990) offers a thorough and compelling overview of this fascinating and highly contentious subject. As my primary line of argumentation does not require identifying the time period to which any of the dialogues examined in this work belong, i.e., the so-called 'early', 'middle', and 'late' periods of Plato's career and, given the complex and controversial nature of definitively establishing such a chronology, I have chosen not to take up this issue in my exploration of Platonic wonder. 


\section{THE WONDER OF HUMANITY}

What types of considerations or things induce wonder in the characters, the dramatis personae, found in Plato's dialogues? The source of astonishment for Theaetetus in the epigraph that opens this paper is a numerical puzzle, forwarded by Socrates, which reveals that the youth's beliefs concerning the process of becoming and number contradict one another. ${ }^{6} \mathrm{~A}$ second example occurs during Socrates' speech in the Symposium, where the philosopher recounts the instruction he received from Diotima of Mantinea concerning the true nature of Eros. According to Diotima, after the true lover beholds "successively and correctly the beautiful things," starting from the love of a beautiful body and ascending through beautiful souls, institutions and laws, the sciences, and ending with a "certain single philosophical science," he will be rewarded with a vision of that which is ti thaumaston ten phusin kalon, "something wonderfully beautiful in nature," i.e., the Form of beauty itself." Or, as a final example of what evokes wonder in the dialogues, let us recall Glaucon's presentation of the myth of Gyges in the second book of the Republic. Here Glaucon weaves a tale wherein a certain Lydian shepherd, who Glaucon identifies as an ancestor of Gyges, was tending his flock when a tremendous thunderstorm and earthquake suddenly broke out. Afterwards, the shepherd noticed that the ground had split open and a chasm had formed at the very spot where his sheep normally grazed. We are told that the shepherd "saw it, wondered [thaumasanta] at it, and went down. He saw, along with other quite wonderful [thaumasta] things about which they tell tales, a hollow bronze horse. It had windows; peeping in, he saw there was a corpse inside that looked larger than human size." 8

'Theaetetus' wonder is sparked by a mathematical puzzle and the ontological complications that it implies; Diotima speaks of a wondrous beauty that is eternal, unchanging, singular, and self-sufficient; and Gyges' ancestor is wonder-struck by a very large corpse entombed in a metal horse. While puzzles, Forms, and seemingly superhuman bodies are all understandable objects of wonder, one is tempted to ask about the possibility of a different source of wonder in Plato's works, a wonder evoked by the nature of the wondering beings themselves. Wonder of this sort is found in Homer's epic poetry. For example, consider Achilles (Achilleus) and Priam's wonder at one another's appearance and disposition at the end of the Iliad:

But when they had put aside their desire for eating and drinking, Priam, son of Dardanos, gazed upon Achilleus, wondering [thaumaz'] at his size and beauty, for he seemed like an outright vision of gods. Achilleus in turn gazed on

\footnotetext{
6 Plato, Theaetetus, 154b-155c. See also Benardete, “Theaetetus Commentary,” I.106107 in the translation of the dialogue cited above.

7 Plato, Symposium, 210a-211a. Gloss added. Taken from Plato's Symposium, trans. by Seth Benardete (Chicago, IL: The University of Chicago Press, 2001).

8 Plato, Republic, 359d. Gloss added. Taken from The Republic of Plato, trans. by Allan Bloom, 2d ed. (New York, NY: Basic Books, 1991).
} 
Dardanian Priam and wondered [thaumazen], as he saw his brave looks and listened to him talking. 9

In their own respective ways, Athens' great tragedians, such as Sophocles, deal with the wonder of human existence as well. ${ }^{10}$ What, then, can be said about the philosophical dialogues composed by the son of Ariston? Is the human person a wonder or thauma and therefore "worthy of our wonder"11 in these works? Are the individuals who sometimes find themselves caught up in wonder in the dialogues also presented as wonders or thaumata as well? In order to address these questions, we must return to the dialogues themselves. The opening scene of one of Plato's most beloved dialogues, the Phaedrus, will serve as our point of departure.

\section{Wonder, Monsters, And Human Beings: Phaedrus}

$$
\text { Know thyself — Oracle at Delphi }
$$

"Phaedrus, my friend! Where have you been? And where are you going?"12 At the beginning of the Phaedrus, Socrates meets the dialogue's namesake as the latter is about to go beyond the city walls for a stroll in the country. It seems that Phaedrus has spent the morning listening to a speech on love recently composed by his good friend Lysias. Socrates surmises that Phaedrus was regaled with several readings of the speech and now wishes to commit the piece to memory by speaking it out loud beyond earshot of his fellow Athenians. Socrates confesses to his friend that he is a "man who is sick with passion for hearing speeches," and he insists that Phaedrus' reluctance to recite the speech for him now is nothing but a playful ruse; the youth should stop playing "coy" and present the speech that has obviously occupied him for the entire morning. ${ }^{13}$ Phaedrus agrees to share Lysias' speech with Socrates, and with this agreement the two Athenians head off into the surrounding countryside toward a "very tall plane tree" that Phaedrus knows of, a tree that casts ample shade and is visited by light breezes. ${ }^{14}$

${ }^{9}$ Homer, Iliad, 24.628-632. Gloss added. Taken from The Iliad of Homer, trans. by Richard Lattimore (Chicago, IL: The University of Chicago Press, 1961).

10 See the section below on Sophocles' Antigone and the Ode to Man.

11 Plato, Republic, 327a.

12 Plato, Phaedrus, 227a. Taken from Phaedrus, trans. by Alexander Nehamas \& Paul Woodruff (Indianapolis, IN: Hackett Publishing Company, 1995).

13 Ibid., 228a-228c. A number of commentators have noted that Socrates' claim that he is "sick with passion for hearing speeches" and a "lover of speeches" is rather odd and more than likely ironic, as Socrates is normally portrayed in the dialogues as preferring elenctic exchange to forays into highfalutin rhetoric. See Nehamas \& Woodruff, "Introduction," xiv-xv, in the translation of the Phaedrus cited above; James A. Arieti, Interpreting Plato: The Dialogues as Drama (Savage, MD: Rowman \& Littlefield Publishers, 1991), 186; Charles L. Griswold Jr., SelfKnowledge in Plato's Phaedrus (New Haven, CT: Yale University Press, 1986), 28-29.

${ }_{14}$ Plato, Phaedrus, 229a-b. 
As they walk alongside the stream Ilisus, Phaedrus points out to Socrates the place where Boreas, the god of the north wind, reportedly kidnapped princess Oreithuia, and he asks Socrates if he holds the story to be true. If he held the story to be false, Socrates responds with thinly veiled irony, he would certainly find a place among many of the prevailing "intellectuals" or sophoi who concern themselves with such matters:

Actually, it would not be out of place for me to reject it, as our intellectuals do. I could then tell a clever story: I could claim that a gust of the North Wind blew her over the rocks where she was playing with Pharmaceia; and once she was killed that way people said she had been carried off by Boreas—or was it, perhaps, from the Areopagus? The story is also told that she was carried away from there instead. ${ }^{15}$

For the sophoi, only a physical or natural explanation of the Oreithuia story is capable of revealing its truth. It was the wind as a naturally occurring phenomenon, and not the mythical personification of the wind, Boreas, that caused Oreithuia to fall to her death. The task of demythologizing the traditional stories in such a manner, according to Socrates, is not an enviable one, as the intellectual who provides one such account may very well feel compelled to go on and offer similar accounts of Gorgons, Hippocentaurs, Chimaera, Pegasuses and other creatures that are marvelous and strange. ${ }^{16}$ Indeed, accounting for all the creatures and events of lore in this way would surely "overwhelm" even the most ambitious individual. ${ }^{17}$ While Socrates obviously has some reservations about explaining the traditional myths in these terms, it is important to note that he does not claim that the intellectuals'

15 Ibid., 229c-d.

16 Ibid., 229d-e. Socrates holds these mythical creatures to be teratologon and atopiai in nature. The word teratologon stems from the word teratologos, and the latter according to LiddellScott means something "of which marvelous things are told" and/or "portentous." The word atopiai stems from the word atopia, which literally means "a being out of the way" and can be rendered as "strangeness" or "oddness." An Intermediate Greek-English Lexicon: Founded Upon the Seventh Edition of Liddell and Scott's Greek-English Lexicon, (Oxford: Clarendon Press, 1999), s.v.

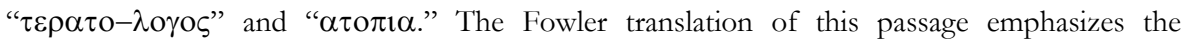
strangeness of these mythical creatures: "But I, Phaedrus, think such explanations are very pretty in general, but are the inventions of a very clever and laborious and not altogether enviable man, for no other reason than because after this he must explain the forms of the Centaurs, and then that of the Chimaera, and there presses in upon him a whole crowd of such creatures, Gorgons and Pegas, and multitudes of strange, inconceivable, portentous natures." Taken from Plato in Twelve Volumes, Vol. 9, trans. by H.N. Fowler (Cambridge, MA: Harvard University Press, 1925).

17 Plato, Phaedrus, 229e. For a thorough treatment of Socrates' aversion to reductive explanations of the traditional myths, see Griswold, Self-Knowledge in Plato's Phaedrus, 36-39. See also G.R.F. Ferrari, Listening to the Cicadas: A Study of Plato's Phaedrus (Cambridge: Cambridge University Press, 1987), 9-12; Graeme Nicholson, Plato's Phaedrus: The Philosophy of Love (West Lafayette, IN: Purdue University Press, 1999), 15-24. 


\section{BOLLERT 179}

accounts are necessarily wrong. ${ }^{18}$ Thus, Socrates' reservations about interpreting the traditional myths à la the sophoi may have more to do with a belief that accounting for all fabled creatures and events in this manner would constitute a labor beyond Herculean than a conviction concerning the epistemic worth of such accounts as such. Still, even if Socrates believes that physical accounts of the traditional myths do hold some epistemic promise, it is clear that he is neither opposed to nor aligned against myth qua myth in the Phaedrus. Indeed, we shall soon see that Socrates adverts to and makes use of a mythical creature for his own philosophical purposes in this dialogue. The fact of the matter is that Socrates simply does not have time to spare for studying or formulating any more natural accounts of legendary creatures or events. What, then, does Socrates have time to investigate? What does lay claim to his attention, grip him, or provoke his wonder?

The reason why Socrates has no time to explain the traditional myths in physical or natural terms is that he has yet to fully plumb the depths of his own soul. ${ }^{19}$ Socrates holds that he must first come to terms with his own nature before he can sensibly turn his attention to other matters:

But I have no time for such things; and the reason, my friend, is this. I am still unable, as the Delphic inscription orders, to know myself; and it really seems to me ridiculous to look into other things before I have understood that. This is why I do not concern myself with them. I accept what is generally believed, and, as I was just saying, I look not into them but into my own self: Am I a beast more complicated and savage than Typho, or am I a tamer, simpler animal with a share in a divine and gentle nature?20

As we know from the Phaedo, there was a time when naturalistic accounts of the vast and variegated phenomena of the world fascinated Socrates, a time when as a young man he was "wondrously desirous [thaumastos hos epethumesa] of that wisdom they call 'inquiry into nature.." 21 The Socrates we meet in the Phaedrus, however, now finds that there is more than enough wonder that envelops the human person in general, and his own soul in particular, to occupy his time. He is a mystery to himself, and no less a god than Apollo commands him to study his own soul before turning his attention to other

\footnotetext{
18 Griswold, Self-Knowledge in Plato's Phaedrus, 37.

19 Plato, Phaedrus, 229d-230e.

20 Ibid., 229e-230a.

${ }^{21}$ Plato, Phaedo, 96a. Gloss added. Plato's Phaedo, trans. by Eva Brann, Peter Kalkavage, and Eric Salem (Newburyport, MA: Focus Publishing/R Pullins Company, 1998). Concerning Socrates' interest in nature, the translators offer the following note: "In Aristophanes' Clouds, Socrates is lampooned for his acquaintance with the opinions of the so-called "physicists," who speculated on the constitution of the visible world (225 ff.)." Nicholson also draws a connection between the Phaedrus and the Phaedo on this issue. See Nicholson, Plato's Phaedrus: The Philosophy
} of Love, 21. 
matters such as devising physical accounts of the traditional myths. He is a wonder to himself, a wonder that rivals if not surpasses the marvelous nature of any and all mythical monsters. As Benjamin Jowett puts it: "'the proper study of mankind is man,' who is a far more complex and wonderful being than the serpent Typhon." 22

\section{Hesiod and Typho}

From his shoulders grew a bundred heads of a snake, a fearful dragon, with dark, flickering tongues, and from under the brows of his eyes in bis marvellous heads flashed fire, and fire burned from his heads as he glared. - Hesiod, Theogony

Of all the creatures found in stories and legends, why does Socrates mention Typho as he discusses his ongoing quest for self-knowledge with Phaedrus? According to Hesiod, Typho (Typhon, Typhoeus) is the child of Earth and Tartarus and was born shortly after Zeus had cast the Titans out of Heaven. ${ }^{23}$ The poet describes Typho as a "fearful dragon," a deinoio drakontos, who possesses terrible strength, multiple serpentine heads, and a scorching gaze. ${ }^{24}$ The monster's "marvellous" heads would emit uncanny voices and sounds, roars, bellows, and whelps, all of which were thaumat' akousai or "wonderful to hear." 25 Quickly perceiving that Typho had designs on ruling humanity and the immortals alike, Zeus engaged the creature in a vicious battle and eventually proved victorious, casting the "maimed wreck" that was once proud Typho into "wide Tartarus." 26 Even in this diminished state, Typho still continues to issue "boisterous winds" that destroy ships and sailors alike. ${ }^{27}$ According to Hesiod, the only winds that are a "great blessing to men" are Boreas, Notus, and Zephyr, as they alone are winds of the "god-sent kind."28 Who or what, then, is Socrates? Is the philosopher a "god-sent" human being

22 Benjamin Jowett, "Introduction to the Phaedrus," 361, as found in The Works of Plato, trans. by B. Jowett (New York, NY: The Dial Press, 1936). See also Paul Friedländer, Plato: The Dialogues, Second and Third Periods, trans. by Hans Meyerhoff (Princeton, NJ: Princeton University Press, 1969), 220: "Yet, all along, it ultimately is the same Socrates we meet. He wants to "know himself," for he is a riddle to himself (229e et. seq.), and his "strangeness" ( $\alpha \tau 0 \pi 1 \alpha)$ is as astonishing here $(229 \mathrm{c} 6,230 \mathrm{c} 6)$ to Phaidros as it is to Alkibiades in the Alkibiades Major (106a) and in the Symposium (215a)." Nehamas and Woordruff ("Introduction," ix-x) compare and contrast the monsters faced by Socrates and Odysseus, respectively: "Odysseus met external enemies: strange gods, weird monsters, unknown peoples. Socrates, who claims that, not "knowing himself," he wonders whether he is "a beast more complicated and savage than Typho, or. . . a tamer, simpler animal with a share in a divine and gentle nature," discovers by the banks of the river Ilisus parts of himself he had never known before. The "monsters" he meets, though not malevolent, come from within."

${ }^{23}$ Hesiod, Theogony, 820-823. Taken from Hesiod: The Homeric Hymns and Homerica, trans. by Hugh G. Evelyn-White (Cambridge, MA: Harvard University Press, 1914).

${ }^{24}$ Ibid., 825-829.

${ }^{25}$ Ibid., 829-834.

${ }^{26}$ Ibid., 836-868.

27 Ibid., 868-876.

28 Ibid., 870-871. 
who is capable of benefiting those he encounters, like his friend Phaedrus, or is he rather a sender of ruinous winds?

\section{Deinos and the Ode to Man}

The repetition of the key words, deina. . . deinoteron, forms a strong emphasis and opens a range of possible meanings: fearsome and marvelous, potent and strange, mighty and resourceful, wonderful but also terrifying. - Robert F. Gobeen, The Imagery of Sophocles' Antigone

In speaking of winds, waters, and a man who might be deinoio or "fearful" in nature, one is reminded of the first lines of the famous Ode to Man as found in Sophocles' Antigone:

polla ta deina kouden anthropou deinoteron pelei. touto kai poliou peran pontou cheimerioi notoi

chorei, peribruchioisin

peron bup'oidmasin.

Many are the wonders, none

is more wonderful than what is man.

This it is that crosses the sea

with the south winds storming and the waves swelling, breaking around him in roaring surf. ${ }^{29}$

The words deina and deinoteron, which David Grene translates as "wonders" and "wonderful" in this passage, as well as deinoio, the word which Hesiod uses to describe Typho, all stem from deinos, a polyvalent word which can mean, amongst other things, that which brings about a sense of wonder, but it can also mean that which is strange or uncanny, terrible, fearful, or dreadful. ${ }^{30}$ As Martha Nussbaum observes, the word can indicate that which evokes an affirming wonder with respect to a human being and that which is uncanny or

29 Sophocles, Antigone, 368-372. Greek. Tragedies, ed. by David Grene and Richard Lattimore, 2d ed., vol. 1 (Chicago, IL: The University of Chicago Press, 1991). David Grene is the translator of Antigone in this volume. Cited lines will follow Grene's line numbers for the translated text in this volume.

30 George Steiner's observation concerning the sheer volume and diversity of interpretations of the choral ode in general (and specifically the word deinon) is apposite here: "To list the literature which has accumulated around the second stasimon in Antigone would be to establish a bibliography of studies in Sophocles." George Steiner, Antigones (Oxford: Clarendon Press, 1984), 174. For example, see Robert F. Goheen, The Imagery of Sophocles' Antigone: A Study of Poetic Language and Structure (Princeton, NJ: Princeton University Press, 1951), 53-54; Martha Nussbaum, The Fragility of Goodness, rev. ed. (Cambridge: Cambridge University Press, 2001), $52-$ 53. 
even monstrous in humanity. ${ }^{31}$ In this vein, Nussbaum goes on to note that the chorus refers to "man" by using the neuter pronoun in line 335 ("This it is that crosses the sea. . . "), thereby lending further emphasis to humanity's strangeness. ${ }^{32}$ What, then, is a human being? A monster, perhaps? A rational being? Both? Socrates, too, is perplexed about his nature: Is he monstrous like Typho, the creature with a hundred heads, or is he a "tamer, simpler animal," blessed by the divine with reason, speech, and civility? When we reflect on these considerations with care and honesty, it becomes increasingly difficult to remain indifferent to the principle that grounds Socrates' self-inquiry and explains his reluctance to interpret the traditional myths in the manner of the prevailing intellectuals. This principle can be stated in the form of a question: Why should we seek out natural explanations of the strange beings and creatures of lore when we still are a mystery to ourselves?

Perhaps Phaedrus himself puts it best. Upon reaching the plane tree, Socrates suddenly becomes enchanted with the immediate surroundings. In a manner befitting an inspired poet, the philosopher proceeds to sing the praises of the river's cool water and the "sweet song of the cicadas' chorus" that fills the air. ${ }^{33}$ Phaedrus is quite surprised by Socrates' enthusiasm: "But you, you amazing man, appear to be very much out of place!" 34 Phaedrus' word choice is exceedingly significant: Socrates is "amazing" (thaumasie) and "very much out of place" (atopotatos). Ian Leask observes that atopotatos is the superlative form of atopos, a word whose meanings include 'out of place', 'out of the way', and 'strange'. ${ }^{35}$ Phaedrus holds Socrates to be amazing precisely because it is quite strange or out of place for this philosopher, who spends the vast majority of his time philosophizing within the confines of the city, to be waxing poetic about the splendors of nature by a river in the countryside. ${ }^{36}$ In this sense,

${ }^{31}$ Nussbaum, The Fragility of Goodness, 52-53: “The human being, who appears to be thrilling and wonderful, may turn out at the same time to be monstrous in its ambition to simplify and control the world."

32 Ibid., 73: " 'This thing,' they say, using the neuter pronoun, distancing themselves from the strangeness of this creature, attempting to give a dispassionate story of its nature and its behavior, "crossing the gray sea...."'

33 Plato, Phaedrus, 230b-c.

34 Plato, Phaedrus, 230c. Taken from Phaedrus, trans. by James H. Nichols, Jr. (Ithaca, NY: Cornell University Press, 1998). Compare Nichols' rendering of this key line from the Phaedrus with Nehamas and Woodruff's rendering: "And you, my remarkable friend, appear to be totally out of place." It seems to me that by translating thaumasie as "amazing" instead of "remarkable," Nichols better captures Socrates' wondrousness than Nehamas and Woodruff do in their otherwise fine translation. This is the only instance in which I draw upon Nichols' translation of the Phaedrus.

35 With respect to the various connotations of the word atopos, Leask cites Liddell and Scott's Greek-English Dictionary. See Ian Leask, "Strangely out of Place: Phaedrus 227a-230e," 206 in Between System and Poetics: William Desmond And Philosophy After Dialectics, ed. by T. Kelly (Burlington, VT: Ashgate Publishing Company, 2007). See also note 16 above.

36 Plato, Phaedrus, 230c-d. At this point in dialogue, Phaedrus observes the following to Socrates: "Not only do you never travel abroad—as far as I can tell, you never even set foot beyond the city walls." Socrates responds by noting that the people in the city are better teachers than the scenery and flora one finds in the country: "Forgive me, my friend. I am devoted to 
Phaedrus' surprise and exclamatory remark are understandable. At a deeper level, however, Phaedrus' remark comes remarkably close to expressing what Socrates told him moments before, namely that the philosopher has yet to achieve what the Delphic inscription commands. Socrates does not yet know himself. He is not entirely sure what he is or where he belongs. Hasn't Socrates, the rational inquirer par excellence, already admitted that he may have more in common with a monster like Typho than he currently realizes? Might he not be more strange or marvelous than the mythical creatures that the intellectuals seek to understand in naturalistic terms? Perhaps more than he is capable of understanding, Phaedrus has provided Socrates with the most appropriate sobriquet imaginable: "amazing man." Within or without the city walls, Socrates is, and will likely remain, as amazing and strange to himself as he is to others. Like the Chorus in Antigone, Socrates finds that there is more than enough wonder evoked by human nature in general, and his own nature in particular, to last a lifetime.

There are other moments in the Platonic dialogues when the wondrous nature of the human person comes to light. Alcibiades, in his drunken encomium to Socrates at the end of the Symposium, provides us with a second and especially illuminating example of this type of wonder, and it is to this memorable speech that we will now turn.

\title{
A Wonder and a Wonderer: Symposium
}

\begin{abstract}
ALCIBLADES: Now, one could praise Socrates for many other amazing things; but whereas for the rest of his pursuits—one might perhaps say the like about someone else as well—what deserves all wonder is that respect in which he is like no buman being, neither the ancients nor those of the present day. — Plato, Symposium
\end{abstract}

The Symposium presents a series of eulogies in honor of Eros given by Socrates, the comic poet Aristophanes, and others at a party hosted by the tragic playwright Agathon. Immediately after Socrates' eulogy of Eros, a commotion erupts in Agathon's courtyard. An intoxicated Alcibiades, with a flute girl and fellow revelers in tow, has come to congratulate Agathon on his first victory as a tragedian. Drunk with wine and wearing fillets in his hair, Alcibiades bears an unmistakable resemblance to the god Dionysus. As Alcibiades sits down next to Agathon, seeking to weave a wreath from his fillets in order to crown the victorious playwright, he suddenly realizes that he does not share the couch with Agathon alone; much to Alcibiades' surprise and apparent consternation, a third party, one who has long tormented him, is reclining on the couch as well:

Heracles! What is the meaning of this? Socrates is here? Once again you lie in ambush; and just as is your habit,

learning; landscapes and trees have nothing to teach me-only the people in the city can do that." 
you appear suddenly wherever I believed you were least likely to be. And now, why have you come? And why did you lie down here? For it is not with Aristophanes, or with anyone else who is - or wants to be-laughable that you lie; but you managed it so that you lie down beside the most beautiful of those in the room. ${ }^{37}$

Socrates responds to Alcibiades' not-so-gentle reproach by asking for Agathon's assistance, confiding to the tragedian that his love of Alcibiades has brought him a horde of problems. Indeed, Alcibiades now becomes fiercely jealous whenever Socrates converses with or even glances at another beautiful human being, and in such a state Athens' darling has done some mad and "amazing [thaumasta] things" to him. ${ }^{38}$ Yet, as Alcibiades will soon reveal, it is Socrates whose words and deeds are truly amazing.

Although Alcibiades insists that he cannot be reconciled to Socrates, he still feels compelled to crown his tormenter in addition to wreathing Agathon, for while the playwright does have one impressive victory to his credit, Socrates' conquests are simply vast in number: "[Agathon] . . . spare us some of the fillets, so that I may wreathe this amazing head [thaumasten kephalen] of his; and he need not reproach me because I wreathed you, and not him; for he conquers all human beings in speeches, and not just the day before yesterday as you did, but at all times." ${ }^{39}$ Like the other guests, Alcibiades will earn his drink by providing a eulogy, but unlike the others he will not sing the praises of Eros. Instead, Alcibiades will praise the one person who has proven to be somewhat impervious to his striking beauty and charm. And so Alcibiades begins his eulogy of Socrates.

Alcibiades must rely upon "likenesses" in his praise of Socrates. ${ }^{40} \mathrm{He}$ begins by comparing Socrates to the little statues found in the sculptors' shops whose outlandish exteriors belie their beautiful interiors. Erasmus describes these statues, called sileni, in the following way: "It seems the Sileni were statuettes divided in half and put together so that they could be opened up and the interior displayed. When closed they portrayed some ridiculous and monstrous flute player, but when opened all of a sudden they displayed a god." ${ }^{41}$ Alcibiades also compares Socrates with the satyr Marsyas. Like the famous satyr, Socrates is able to enchant those who listen to him despite his rather ugly appearance. Yet Alcibiades holds Socrates to be "far more marvelous [thaumasioteros] to be sure, than Marsyas," as the satyr uses a flute to transfix his listeners, while Socrates can "charm" his listeners through the

${ }^{37}$ Plato, Symposium, 213b-c.

38 Ibid., 213c-d. Gloss added.

${ }^{39}$ Ibid., 213d-e. Gloss added.

${ }^{40} \mathrm{Ibid}$., $215 \mathrm{a}$.

${ }^{41}$ Erasmus, "The Sileni of Alcibiades," 169. Taken from Utopia, With Erasmus's The Sileni of Alcibiades, ed. and trans. by David Wootton (Indianapolis, IN: Hackett Publishing Company, 1999). 
power of his words alone.42 Included in the ranks of those who have experienced the force and sway of Socrates' words is Alcibiades himself. Normally reveling in the honors and glories bestowed upon him by his fellow Athenians, Alcibiades confesses that Socrates alone can make him feel ashamed of playing to the wishes of the crowd instead of caring for his own soul. ${ }^{43}$ But this account only scratches the surface of this enigmatic man, and much more must be said about Socrates and "how amazing [thaumasian] is the power he has." 44

According to his eulogist, Socrates is truly silenic, for he wraps himself in the guise of a man who is erotically "thunderstruck" by youthful beauty. ${ }^{45}$ However, if one delves beneath this guise, one discovers that Socrates, although not entirely immune to the charms of physical beauty, is far more taken with beautiful souls than he is with beautiful bodies. ${ }^{46}$ It turns out that the physically beautiful Alcibiades has also been enthralled by a beautiful soul in the past, namely the soul of the man that he is currently eulogizing. There once was a moment when Socrates briefly dropped his customary veil of irony and truly unfolded himself to Alcibiades, and the latter found that within this silenic human being dwelled "images" of wondrous beauty:

And when he is in earnest and opened up, I do not know if anyone has seen the images within; but I once saw them, and it was my opinion that they were so divine, golden, altogether beautiful, and amazing [thaumasta] that one had to do just about whatever Socrates commanded. ${ }^{47}$

Continuing his eulogy, Alcibiades admits that he once tried to seduce Socrates and failed spectacularly. Such a failure was undoubtedly rare for Alcibiades, and only an exceedingly rare individual could be responsible for it. Indeed, only a "daemonic [daimonioi] and amazing [thaumastoi] being" like Socrates could rebuff the advances of the handsome and charming Alcibiades, and only such a man, despite this "magnificently overweening deed," could still be loved and admired for his "nature, moderation, and courage" by the "dishonored" Alcibiades. ${ }^{48}$

The next stage of Alcibiades' speech deals with Socrates' deeds during two different military campaigns. While campaigning at Potidaea, Socrates displayed far better "self-control" than his fellow soldiers when the enemy temporarily cut off their food supplies. ${ }^{49}$ The philosopher's self-control,

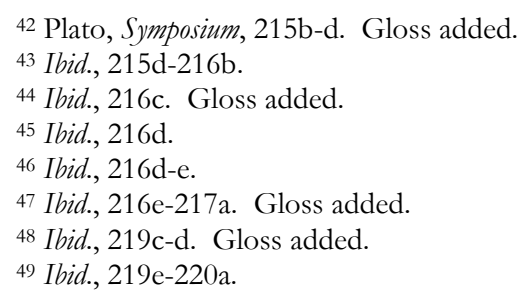




\section{THE WONDER OF HUMANITY}

according to Alcibiades, was no less impressive when it came to passing the cup:

And again at festivities he alone was able to take pleasure in other things, and in drinking as well; for even though he wasn't willing to drink, whenever he was compelled to do so, he outdid everybody; and what is the most amazing [thaumastotaton] thing of all, no human being has ever seen Socrates drunk. ${ }^{50}$

Unrivaled in terms of controlling his hunger and handling his drink, no one could match Socrates' indifference to the brutal cold of winter as well: “. . . in regard to resistance against the winter-for winters are terrible there-all the rest he did was amazing [thaumasia]." 51 In the midst of a frost so horrific that those who dared to go outside did so wrapped "in an amazing [thaumasta] number of garments," Socrates went barefoot and still made better time than his "shod" companions. ${ }^{52}$

While enduring the pangs of hunger, the dizzying effects of spirited drink, and the brutal cold with patience and equanimity are all noteworthy deeds, they nevertheless pale in comparison to the twenty-four hour bout of astonishment that Socrates endured on this campaign:

'What sort of thing the strong man did and dared'53there on campaign once, is worth hearing. Once, he had gotten a thought, and he stood on the same spot from dawn on, considering it; and when he made no progress, he did not let up but stood searching. And it was already noon, and the men became aware of it; and in amazement one said to another that Socrates had stood there in reflection since dawn. And finally some Ionians, when it was evening and they had dined-for it was then summerbrought out their pallets and slept in the cold and watched to see if he would also stand during the night. And he stood until it was dawn and the sun came up; and then having made a prayer to the sun he went away. ${ }^{54}$

Alcibiades will go on to recall how Socrates saved his life and weapons on this campaign, and he will also recount a second campaign at Delium where Socrates, in the midst of a collective retreat after been routed by the enemy, proceeded with an almost uncanny calm, "'stalking like a pelican, his eyes

\footnotetext{
${ }^{50}$ Ibid., 220a. Gloss added.

${ }^{51}$ Ibid., 220a. Gloss added.

52 Ibid., 220a-b. Gloss added.

53 “Homer, Odyssey, 4.242, 271." Translator's footnote.

54 Plato, Symposium, 220c-d.
} 
darting from side to side," ${ }_{55}$ making it plain to all and sundry that he was a capable man who should simply be left alone. ${ }^{56}$ For many of us, however, it is the image of Socrates standing stock still for an entire day in camp, caught up and transfixed by such an intense wonder as to evoke "amazement" (thaumazontes) in his fellow soldiers, that endures most vividly. Others have proved their courage in the field of battle, but has there ever been another human being who could match Socrates' philosophical vigilance, standing watch over a wonder so unrelenting as to see the light of a moon and two dawns? The wondering Ionian soldiers-who, hailing from the same land as Thales, come from good stock when it comes to wonder-is supplemented by food, blankets, and intermittent sleep. The wily Odysseus stood enrapt at the song of the Sirens, but he was strapped fast to a mast of unyielding wood. ${ }^{57}$ The grip of Socrates' wonder, however, is as sure and steadfast as Odysseus' bonds. Astonishingly, the hunger, cold, and exhaustion that would surely diminish if not destroy the thaumazein of most other human beings can simply gain no purchase on Socrates' soul as he stands transfixed among the marveling Ionians.

Alcibiades ends his eulogy of Socrates by remarking upon the latter's singular nature:

Now, one could praise Socrates for many other amazing [thaumasia] things; but whereas for the rest of his pursuits—one might perhaps say the like about someone else as well-what deserves all wonder [pantos thaumatos] is that respect in which he is like no human being, neither the ancients nor those of the present day. ${ }^{58}$

Alcibiades observes that Brasidas may be compared to Achilles, and Pericles may be compared to Nestor or Antenor, but where can one find Socrates' likeness?59 Socrates" "strangeness" (atopian) is simply incomparable "both in himself and in his speeches." 60 Who else makes speeches that constantly refer to "pack-asses, blacksmiths, shoemakers, and tanners," giving the illusion that the philosopher "is always saying the same things through the same things," when in truth these speeches are unmatched in terms of being sensible, godly, and a guiding light for those who wish to be "beautiful and good"? ${ }^{61}$ No matter where he looks, Alcibiades simply cannot find a human analogue for his beloved Socrates; the latter is akin, if he is akin to anything at all, to the "silenuses and satyrs." ${ }^{2}$ Ugly in his countenance yet beautiful from within,

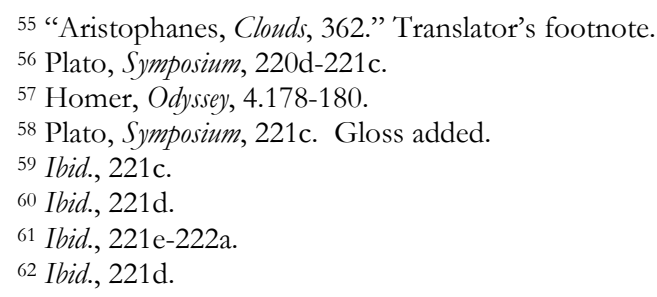


seemingly obsessed with lovely bodies yet truthfully more taken with virtuous souls, and offering speeches that are as profound in their meaning as they are simple in their terms, Socrates' unique nature truly merits "all wonder."

Of course, Plato's account of humanity's wondrous nature is not limited to a presentation of the strange or uncanny elements that dwell within Socrates or any other human being. Plato is not a circus barker with a philosophical bent who only offers up the more outlandish aspects of the human person so that we may gawk, stare, and sate our lust for that which is odd. For instance, one of the most beautiful expressions of wonder in the dialogues occurs in the Phaedo, and its object is neither 'typhonic' nor silenic. Instead, it is the concern of a remarkable friend that provokes a deep sense of wonder in the dialogue's namesake. Let us turn, then, to the Phaedo. ${ }^{63}$

\section{Wondrous Songs: Phaedo}

PHAEDO: For my part, wondrous were the things I experienced when I was present. — Plato, Phaedo

It is difficult to read the Phaedo and not be inspired by Socrates' dignified and resolute bearing as he prepares to drink the hemlock. JacquesLouis David's famous painting of the philosopher's final moments, The Death of Socrates, perfectly captures the gadfly's calm at the moment of truth; reaching for the cup of hemlock with one hand while pointing to the heavens with the other, we see Socrates admonishing his friends to dedicate their lives to the highest matters. The painting also captures the grief felt by the other characters in the Phaedo, and a good number of its readers, despite Socrates' best efforts to persuade them that death will not destroy what is truly important: his soul. As we shall see, these efforts reflect the care of a true friend, and it is this care that calls for our greatest wonder.

"For my part, wondrous [thaumasia] were the things I experienced when I was present." 64 With these words, Phaedo, for the benefit of his friend Echecrates, begins his narrative account of what transpired that fateful day in the prison cell before Socrates drank the hemlock. A recollection and a declaration of wonder, then, set the dialogue in motion. Indeed, there are quite a few "wondrous" things that come up during Socrates' last day of philosophical discussion, including four arguments for and two arguments against the immortality of the soul. ${ }^{65}$ Although the arguments themselves are wondrous enough, they are not the greatest source of wonder in this work. At

${ }^{63} \mathrm{My}$ reading of this particular section of the Phaedo is deeply indebted to the "Introduction" written by Brann, Kalkavage, and Salem in their translation of the Phaedo cited above.

${ }^{64}$ Plato, Phaedo, 58e. Gloss added.

${ }^{65}$ In the introduction to their translation of the Phaedo, Brann, Kalkavage, and Salem designate the four arguments as "the argument from contraries, the argument from recollection, the argument from invisibility, and the argument from cause." See Brann, Kalkavage, and Salem, "Introduction," 4. 
$88 \mathrm{c}$ of the dialogue, immediately after Phaedo recounts two powerful arguments against the immortality of the soul raised by Simmias and Cebes, two members of the group gathered in Socrates' cell, Echecrates interrupts his friend's narrative with the following interjection:

By the gods, Phaedo, I have real sympathy for all of you! For as I myself now listen to you, it occurs to me to say something like this to myself: "What argument will we trust from now on? The one that was so powerfully trustworthy-the argument that Socrates gave-has now fallen into discredit." For this argument, that our soul is a sort of tuning has now, as ever, a wonderful [thaumastos] hold on me, and your speaking of it reminded me, as it were, that up till now all this seemed to be the case to me too. And now what I really need is some other argument which will, from a new beginning as it were, persuade me that when somebody dies, the soul won't die along with him. So tell me, by Zeus, in what direction did Socrates pursue the argument? And which was it: Did he too, as you say the rest of you did, reveal in any way that he was distressed; or didn't he, and did he instead come serenely to the aid of the argument? And was his aid sufficient, or did it fall short? Go through everything for us as precisely as you can. ${ }^{66}$

I will forgo commenting on Cebes' argument and focus instead on Simmias', as it is the latter's position that seems to trouble Echecrates the most. The Pythagorean view that the soul "is a sort of tuning" has always had a "wonderful hold" on Echecrates, and Simmias has seemingly laid waste to it by means of introducing a counterargument based on the image of a tuned lyre. ${ }^{67}$ Imagine that the soul is akin to the body in the same way that the tuning of a lyre is akin to the lyre. If the tuning of the lyre ceases to be when the instrument itself is destroyed, is it not the case that the soul will share the same fate when the body dies? After considering Phaedo's recounting of this argument, Echecrates now succumbs to the same doubt and dejection that befell Phaedo and the rest of Socrates' companions during the original discussion. Invoking the divine twice, Echecrates expresses "sympathy" for those who gathered that day in the prison cell and, more ominously, a waning faith in the worth of philosophical argumentation itself: "What argument will we trust from now on?" 'Misology', literally a "hatred of reason," is the term that Plato coins for this mistrust of argumentation. ${ }^{68}$ The same specter of misology that threatened Phaedo and the others in the cell now threatens

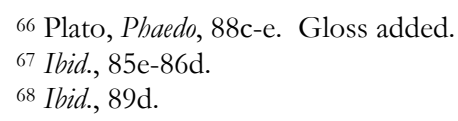


Echecrates, and he implores Phaedo to resume his account, wondering aloud if Socrates too had become "distressed" at this crucial moment in the discussion. What did the examined life's peerless practitioner and advocate do when he found his friends' trust in arguments beginning to crumble?69

As Echecrates' current distress shows, the threat of misology is everpresent, and his interest in how Socrates confronted such an ominous foe is perfectly understandable. According to Phaedo, Socrates' response to the collective distress of those present in his cell was both admirable and wondrous:

Although, Echecrates, I'd often wondered [thaumasas] at Socrates, I never admired [egasthen] him more than when I was present with him then. That he should have something to say was perhaps not out of the ordinary. No, what I really wondered [ethaumasa] at him for was this: first, how pleasantly and kindly and admiringly [agamenos] he received the young men's arguments, then how keenly he perceived how we'd suffered under their arguments, then how well he healed us and, as if we were men who'd fled and been laid low, rallied us and turned us about to follow him and consider the argument. ${ }^{70}$

As it is "not out of the ordinary," as Phaedo puts it, for Socrates to not find himself at a loss for words, so too is it not out of the ordinary for Phaedo to find himself, to use Jerome Miller's exquisite phrase, "in the throe of wonder" in the presence of Socrates..$^{71}$ Indeed, it is Phaedo who opens his narration by noting the "wondrous" events that he experienced during Socrates' last day. With this in mind, let us take a closer look at what provokes Phaedo's wonder at this key moment in the dialogue.

The fact that Socrates has a ready response to the seemingly devastating arguments against the immortality of the soul is not the primary cause of Phaedo's wonder. Socrates has spent the better part of a lifetime engaged in dialectical exchange and examining arguments, so it is not

69 Plato, Apology, 38a: "If, on the other hand, I say that this is a very great good for a human being- to make speeches every day about virtue and other things of which you have heard me speak when examining myself and others, and that for a human being the unexamined life is not worth living, still less, when I say these things, will you be persuaded by me. Yet, such is the case, as I affirm, men, however to persuade you is not easy." Taken from Plato and Xenophon: Apologies, trans. by Mark Kremer (Newburyport, MA: Focus Publishing, 2006).

70 Plato, Phaedo, 88e-89a. Gloss added. Both egasthen and agamenos stem from the word agamai, a word whose various meanings include to wonder, to be astonished, and to admire a person or thing. See An Intermediate Greek-English Lexicon: Founded Upon the Seventh Edition of Liddell and Scott's Greek-English Lexicon, s.v. "AГAMAI." With respect to Phaedo's use of these terms, the meaning seems to be a combination of admiration and wonder or an admiring wonder. Press, 1992).

${ }^{71}$ Jerome Miller, In the Throe of Wonder (Albany, NY: State University of New York 
astonishing that he has something to say about Simmias and Cebes' arguments as such. Rather, Phaedo's wonder is incited by a combination of Socrates' openness to the arguments, the philosopher's discernment of his friends' suffering in light of what the arguments imply, and his skillful healing of their distress. Unlike the others present, whose hopes for an argument establishing the immortality of the soul have been dashed upon the rocks, Socrates is neither daunted nor depressed by Simmias and Cebes' respective challenges. Instead, the philosopher admires the quality of their arguments and, we can safely assume, the honesty and respect for true philosophical discussion that they reflect. Even as his final hour quickly approaches, Socrates remains open to and even encourages a critical assessment of his arguments; the philosopher's time may be growing short, but he himself does not become short with those who find fault with his views. No less wondrous than Socrates' gentle reception of these challenges is the philosopher's recognition of just how severely his friends have been shaken by them. Socrates' friends are now at great risk of succumbing entirely to misology, and the philosopher simply refuses to leave them in such a vulnerable state, as "it's not possible. . . for anybody to experience a greater evil than hating arguments." 72 While many find their empathy for the plight of others blunted when they are forced to deal with a minor inconvenience or trivial annoyance, Socrates' concern for his friends' well-being remains acute even in the face of his own imminent death. Finally, the wounds inflicted by misology, even in its incipient stage, run deep, perhaps far more deep than any that might afflict the body. Given the severity of these wounds and the brief amount of time Socrates has to tend them, the philosopher's eventual success as a healer is surely nothing if not wondrous.

Given these considerations, one begins to understand and share Phaedo's amazement at Socrates' disposition and conduct. Indeed, is there a more definitive example of 'other-regarding' behavior in the history of Western philosophy than what is found depicted in these famous passages from the Phaedo? On the day that he is scheduled to die, Socrates is first and foremost concerned with his friends' welfare! Socrates will respond to Simmias and Cebes' challenges, and by means of skillful dialectic and a beautiful myth, he will "sing away," at least for the time being, the threat of misology and the fear of death that plague his companions. ${ }^{73}$ In the last hours of the philosopher's life, it will not only be the virtuosity of Socrates' songs, but the care that grounds the singing itself, which will evoke Phaedo's greatest admiration and wonder. ${ }^{74}$

72 Plato, Phaedo, 89d.

73 Ibid., 77e. Here Socrates speaks of the importance of singing "incantations" to oneself in order to "sing away" one's fears concerning death. See also Brann, Kalkavage, and Salem, "Introduction," 9.

74 In an article entitled "Socratic Wonder and Philosophical Counseling," I also provide an analysis of the relationship between Socrates and wonder in the Phaedrus and the Phaedo. See David Bollert, "Socratic Wonder and Philosophical Counseling," in Philosophical Practice, 5:1 (March 2010), 576-587. 


\title{
Wonder at Thyself: Crito, Charmides, and Theaetetus
}

\author{
THEODORUS: Know well, of all whom I've ever met-and I've \\ consorted with very many-I'm aware of no one yet whose nature is \\ as wonderfully good. — Plato, Theaetetus
}

Upon close reading of the dialogues, one finds many instances of wonder occasioned by different types of human temperament, appearance, and conduct. For example, the opening scene of the Crito reveals the wonder of the dialogue's namesake at the calm and dignified demeanor of Socrates in the face of his impending execution. Socrates awakes in his cell to find Crito, one of his oldest friends, sitting patiently and quietly in the corner, reluctant to adisturb the philosopher's slumber. Socrates is somewhat baffled as to why Crito did not wake him as soon as he entered the cell. Crito, who has arranged for Socrates' escape and hopes to persuade him that it would be wise to flee Athens, answers his old friend in the following way:

Why, indeed, Socrates, I myself would rather not have all this sleeplessness and sorrow. But I have been wondering [thaumazo] at your peaceful slumbers, and that was the reason why I did not awaken you, because I wanted you to be out of pain. I have always thought you happy in the calmness of your temperament; but never did I see the like of the easy, cheerful way in which you bear this calamity. ${ }^{75}$

Socrates is the one who is sentenced to die, yet it is Crito who is losing sleep over Athens' decision to execute his old friend; this seemingly incongruous state of affairs is what throws Crito into a state of wonder. By means of some gentle admonishments and thoughtful discussion, Socrates is finally able to convince Crito that a truly incongruent state of affairs here would entail a mutual disregard for the verdict reached by their fellow citizens under the auspices of Athenian law. Indeed, it would be his escaping from his cell and flouting the laws of Athens-laws that he has benefited from his entire life and implicitly accepted by remaining in the city of his own free will-that Socrates would deem to be truly worthy of his old friend's wonder.

As evidenced by the opening scene of the Charmides, a human being's physical appearance can also evoke wonder in the dialogues. As the dialogue opens, Socrates is telling an unnamed listener about his recent participation in a battle at Potidaea and the enthusiastic welcome he received from his friends when he returned unharmed to Athens. ${ }^{76}$ After answering their questions about the conflict, Socrates proceeds to ask some questions of his own: Have any of the city's young men "become distinguished for wisdom or beauty or both" in

75 Plato, Crito, 43b. Gloss added. Taken from Euthyphro, Apology, Crito, Phaedo, trans. by Benjamin Jowett (Buffalo, NY: Prometheus Books, 1988).

76 Plato, Charmides, 153a. 
his absence? ${ }^{77}$ One of Socrates' comrades, Critias, notes that in terms of beauty, the young Charmides, who happens to be Critias' cousin, is now thought by many to be the "handsomest young man of the day." 78 Charmides soon arrives on the scene, and Socrates' description of the excitement and wonder caused by the youth's beauty is worth quoting in full:

Now nothing is to be measured by me, comrade, for I am simply a white line when it comes to those who are beautiful, because all who have just reached maturity appear beautiful to me. But especially then he appeared wondrous [thaumastos] to me in both stature and beauty, and indeed, at least in my opinion, all the others were in love with him, so excited and confused had they become as he came in. Indeed, many other lovers were also following among those behind him. Now this was not wondrous [thaumaston] on the part of us men; but turning my attention to the boys, I noticed that none of them, not even the littlest, looked anywhere else, but all were contemplating [etheonto] him as if he were a statue. ${ }^{79}$

Socrates admits that all who have reached Charmides' stage of physical development "appear beautiful" to him, but Charmides, in both "stature" and "beauty," is simply "wondrous" and therefore stands out in high relief among Athens' other young men. So astonishing is this young man's beauty that even the children are transfixed by his looks. Socrates notes that all the boys within eyeshot of Charmides, without exception, fell to "contemplating" (etheonto) him as one would contemplate a beautiful "statue." Plato's word choice is significant here. Etheonto stems from the word theaomai, a verb that frequently means to gaze at or behold with wonder. ${ }^{80}$ Of course, Socrates is far more interested in beautiful souls than he is with beautiful bodies, and he proceeds to engage Charmides in a philosophical conversation about the nature of moderation in order to see if the young man is as beautiful within as he is without. Such a concomitance of internal and external beauty would surely be

77 Plato, Charmides, 153b-d. Taken from Plato, Charmides, trans. by Thomas G. West and Grace Starry West (Indianapolis, IN: Hackett Publishing Company, 1986).

${ }^{78}$ Ibid., 154a.

${ }^{79} \mathrm{Ibid}$., 154b-c. Gloss added.

80 Paul Walter Ludwig, Eros \& Polis: Desire and Community in Greek Political Theory (Cambridge: Cambridge University Press, 2002), 276, n. 31. According to Indra McEwen, theaomai is linked with both thaumazein, the act of wondering, and thauma, the object of wonder, in Homer's epic poetry: "The verb thaumazein (to wonder at, marvel) and the noun thauma (a wonder, a marvel) are very closely related to theaomai, for in Homer it is almost invariably what is seen that is wondered at: it is the eyes that marvel." Indra Kagis McEwen, Socrates' Ancestor: An Essay on Architectural Beginnings (Cambridge, MA: The MIT Press, 1993), 21. Charles Segal notes that the word "theatre" itself stems from theaomai and links the verb to wonder as well: "Theatron, 'theatre,' is a space for beholding, derived from the verb theaomai, to behold with wonder." Charles Segal, Interpreting Greek Tragedy: Myth, Poetry, Text (Ithaca, NY: Cornell University Press, 1986), 75. 
marvelous—indeed, it would almost beggar belief_as Charmides' radiant appearance, from Socrates down to the "littlest" boy, has already proven to be a source of considerable wonder.

Finally, let us recall the wonder of the mathematician Theodrous, as depicted in the Theaetetus, at the intellectual gifts and disposition of the dialogue's namesake. At the beginning of the dialogue, Theodorus recalls a conversation he had with Socrates several years ago in which the mathematician described his most promising student at the time, the young Theaetetus, in the following way:

Know well, of all whom I've ever met-and I've consorted with very many-I'm aware of no one yet whose nature is as wonderfully [thaumastos] good. For to be as good a learner as he is, in a way that's hard for anyone to match, and yet to be exceptionally gentle, and on top of this to be manly beyond anyone whatsoever, I would have expected that it doesn't occur and I don't see it occurring, for those who are as sharp as he is, quick witted, and with good memories are for the most part also quickly inclined to bursts of anger, and in darting about they're swept along like unballasted ships, and they grow up more manic than more manly, whereas those in turn who are more grave face up to their lessons somewhat sluggishly and are full of forgetfulness. But he goes so smoothly, so unfalteringly, and so effectively to his lessons and investigations, and all with so much gentleness, just as a stream of olive-oil flows without a sound, as for it be a cause of wonder [thaumasai] that someone his age behaves in this way. ${ }^{81}$

Theodorus has "consorted with very many" students over the course of his teaching career, some of whom may very well have been bright and "gentle" to a certain degree, but he has never come across one like Theaetetus, who possesses both traits in remarkable abundance. Others may learn in fits and starts, but Theaetetus takes to his "lessons" as a fish takes to water or a bird takes to the sky; it is almost as if such "investigations" comprise his natural environment, the medium in which he is most able to flourish and thrive. The students who share Theaetetus' quick wit and reliable memory are likened by Theodorus to "unballasted ships," as they succumb easily to anger and impulsively flit about from place to place; an unpromising adulthood awaits these intelligent but impetuous youth, an adulthood that is "more manic than

81 Plato, Theaetetus, 144a-b. Gloss added. In his essay “. . . A Wonder That One Could Never Aspire To Surpass," John Sallis analyzes the opening of the Theaetetus, including the wonder that surrounds Theaetetus, in great detail. My contention that the thought, bearing, passions, and actions of human beings are frequent and important objects of wonder in Plato's dialogues is both inspired by and indebted to Sallis' excellent essay. 
more manly," and Theodorus clearly believes that the fate of such unstable individuals is not to be envied. Unfortunately, the "grave" students who lack the mania of their more impulsive peers lack their alacrity and ability to retain what they have learned as well. Sailing between the Scylla of "unballasted" acumen and the Charybdis of even-keeled dullness, Theaetetus progresses in his studies with a bearing that is "gentle" yet "manly" and a mind that reliably retains what it so quickly discerns. Such a nature in one so young, according to Theodorus, is indeed a "cause for wonder." 82 As we saw in the epigraph at the beginning of this paper, Theaetetus admits to Socrates that he "wonders exceedingly" about matters both mathematical and ontological, an admission which gives rise to Socrates' famous declaration that wonder is the arche of philosophy. Like Socrates, the exceptional youth invokes in others the very pathos that befalls him with considerable frequency and power. Like Athens' gadfly, Theaetetus is both a wonderer and a wonder of the highest order.

\section{Conclusion}

Plato did not shrink from recognizing the contraditions and complexities in Socrates' nature. For Plato, his teacher was an ineffable, irreducible source of wonder. - James Lesher, "Later Views of the Socrates of Plato's Symposium"

Plato identifies wonder as the origin and sustaining principle of philosophy, and it would be difficult to overstate wonder's importance in the very works in which the philosopher brings the love of wisdom to dramatic life. The passages examined in this paper strongly suggest that Plato not only holds the human person to be the type of being who wonders at things such as mathematical puzzles, transcendent Forms, or superhuman bodies, but that he considers the human person to be a source or object of wonder as well. In short, we are both subject to and causes of thaumazein, the pathos from which philosophy is born and continually nourished. Further, the sheer range of human attributes, affinities, and actions that evoke wonder in the dialogues is itself wondrous. As we have seen, Socrates' calm and dignified bearing in the face of his impending execution; his steadfast refusal to let his friends fall prey to misology; his silent and unwavering twenty-four hour bout of thaumazein at Potidaea; and his possible affinity with Typhon, sileni, and the satyr Marsyas are all, to borrow the gadfly's expression, "worthy of our wonder." No less worthy in this regard are the temperament and intellect of the young Theaetetus and the physical beauty of Charmides. Finally, prudence dictates a cautionary word

82 In her book Knowledge and Self-Knowledge in Plato's Theaetetus, Andrea Tschemplik offers an incisive account of Platonic wonder in general and why Theaetetus evokes wonder in others in particular. See Andrea Tschemplik, Knowledge and Self-Knowledge in Plato's Theaetetus (Lanham, MD-Plymouth: Lexington Books, 2008). While the scope of her excellent book is not limited to an investigation of Platonic wonder alone, Mary-Jane Rubenstein's Strange Wonder: The Closure of Metaphysics and the Opening of Awe includes an insightful and nuanced treatment of the subject. 


\section{THE WONDER OF HUMANITY}

with respect to Platonic wonder. While it is clear that Plato finds the human person to be wondrous in many respects, this does not mean that he ontologically or epistemically privileges the realm of humanity, with its flitting particulars and shadowy opinions, over and above the realm of that which is unchanging, universal, and pellucidly true; to claim this would be to ignore the general sway of such dialogues as the Republic and Phaedo. Instead, I would like to suggest that Plato is simply reminding us that nonhuman entities do not exhaust what is truly "worthy of our wonder." Indeed, perhaps the philosopher simply wishes to add to the Delphic injunction "Know thyself" an exhortative corollary: "Wonder at thyself."

Department of Philosophy, Manhattan College-Riverdale, New York, United States

\section{References}

Arendt, Hannah, "Philosophy and Politics," in Social Research, 1 (Spring, 1990).

Arieti, James A., Interpreting Plato: The Dialogues as Drama (Savage, MD: Rowman \& Littlefield Publishers, 1991).

Bollert, David, "Socratic Wonder and Philosophical Counseling," in Philosophical Practice, 5:1 (March 2010).

Brandwood, Leonard, The Chronology of Plato's Dialogues (Cambridge: Cambridge University Press, 1990).

Erasmus, "The Sileni of Alcibiades," in Utopia, With Erasmus's The Sileni of Alcibiades, ed. and trans. by David Wootton (Indianapolis, IN: Hackett Publishing Company, 1999).

Ferrari, G.R.F., Listening to the Cicadas: A Study of Plato's Phaedrus (Cambridge: Cambridge University Press, 1987).

Fisher, Phillip, Wonder, the Rainbow, and the Aesthetics of Rare Experiences (Cambridge, MA: Harvard University Press, 1998).

Friedländer, Paul, Plato: The Dialogues, Second and Third Periods, trans. by Hans Meyerhoff (Princeton, NJ: Princeton University Press, 1969).

Goheen, Robert F., The Imagery of Sophocles' Antigone: A Study of Poetic Language and Structure (Princeton: Princeton University Press, 1951).

Griswold, Charles L., Self-Knowledge in Plato's Phaedrus (New Haven, CT: Yale University Press, 1986).

Hegel, Georg Wilhelm Friedrich, The Philosophy of History, trans. by J. Sibree (New York, NY: Dover, 1956).

Heidegger, Martin, Basic Questions of Philosophy, trans. by Richard Rojcewicz and Andre Schuwer (Bloomington, IN: Indiana University Press, 1994).

Hepburn, Ronald W., "Wonder," in Wonder and Other Essays (Edinburgh: Edinburgh University Press, 1984).

Hesiod, Theogony, in Hesiod: The Homeric Hymns and Homerica, trans. by Hugh G. Evelyn-White (Cambridge, MA: Harvard University Press, 1914).

Homer, The Iliad of Homer, trans. by Richard Lattimore (Chicago, IL: The University of Chicago Press, 1961). 
Jowett, Benjamin, "Introduction to the Phaedrus," in The Works of Plato, trans. by Benjamin Jowett (New York, NY: The Dial Press, 1936).

Kierkegaard, Søren, Stages on Life's Way, ed. and trans. by Howard V. Hong and Edna H. Hong (Princeton, NJ: Princeton University Press, 1988).

Leask, Ian, "Strangely out of Place: Phaedrus 227a-230e," in Between System and Poetics: William Desmond And Philosophy After Dialectics, ed. by T. Kelly (Burlington, VT: Ashgate Publishing Company, 2007).

Lesher, James, "Later Views of the Socrates of Plato's Symposium," in Socrates in the Nineteenth and Twentieth Centuries, ed. by M. Trapp (Farnham, Surrey: Ashgate Publishing Company, 2007).

Llewelyn, John, "On the saying that philosophy begins in thaumazein," in PostStructuralist Classics, ed. A. Benjamin (London: Routledge, 1988).

Ludwig, Paul W., Eros \& Polis: Desire and Community in Greek Political Theory (Cambridge: Cambridge University Press, 2002).

McEwen, Indris K., Socrates' Ancestor: An Essay on Architectural Beginnings (Cambridge, MA: The MIT Press, 1993).

Miller, Jerome, In the Throe of Wonder (Albany, NY: State University of New York Press, 1992).

Nicholson, Graeme, Plato's Phaedrus: The Philosophy of Love (West Lafayette, IN: Purdue University Press, 1999).

Nussbaum, Martha, The Fragility of Goodness, rev. ed. (Cambridge: Cambridge University Press, 2001).

Plato, Apology, in Plato and Xenophon: Apologies, trans. by Mark Kremer (Newburyport, MA: Focus Publishing, 2006). Charmides, trans. by Thomas G. West and Grace Starry West (Indianapolis, IN: Hackett Publishing Company, 1986). , Crito, in Euthyphro, Apology, Crito, Phaedo, trans. by Benjamin Jowett (Buffalo, NY: Prometheus Books, 1988). Plato's Phaedo, trans. by Eva Brann, Peter Kalkavage, and Eric Salem (Newburyport, MA: Focus Publishing, 1988). Phaedrus, in Plato in Twelve Volumes, Vol. 9, trans. by Harold North

Fowler (Cambridge, MA: Harvard University Press, 1925). , Phaedrus, trans. by Alexander Nehamas and Paul Woodruff (Indianapolis, IN: Hackett Publishing Company, 1995). , Phaedrus, trans. by James H. Nichols, Jr. (Ithaca, NY: Cornell University Press, 1998). The Republic of Plato, trans. by Allan Bloom, 2d ed. (New York, NY: Basic Books, 1991). , Plato's Symposium, trans. by Seth Benardete, with commentaries by Allan Bloom and Seth Benardete (Chicago, IL: The University of Chicago Press, 2001). Plato's Theaetetus: Part I of The Being of the Beautiful, trans. and commentary by Seth Benardete (Chicago, IL: The University of Chicago Press, 1986). The Theaetetus of Plato, ed. by Myles Burnyeat, trans. by M.J. Levett (Indianapolis, IN: Hackett Publishing Company, 1990). 


\section{THE WONDER OF HUMANITY}

Rubenstein, Mary-Jane, Strange Wonder: The Closure of Metaphysics and the Opening of Awe (New York, NY: Columbia University Press, 2009).

Sallis, John, "... A Wonder That One Could Never Aspire To Surpass," in The Path of Archaic Thinking, ed. by K. Maly (Albany, NY: State University of New York Press, 1995).

Segal, Charles, Interpreting Greek Tragedy: Myth, Poetry, Text (Ithaca, NY: Cornell University Press, 1986).

Sophocles, Antigone, in Greek Tragedies, ed. by David Grene and Richard Lattimore, 2d. ed., vol. 1 (Chicago, IL: The University of Chicago Press, 1991).

Steiner, George, Antigones (Oxford: Clarendon Press, 1984).

Tschemplik, Andrea, Knowledge and Self-Knowledge in Plato's Theaetetus (Lanham, MD-Plymouth: Lexington Books, 2008).

Whitehead, Alfred North, Process and Reality: An Essay in Cosmology (New York, NY: Macmillan, 1929). 